
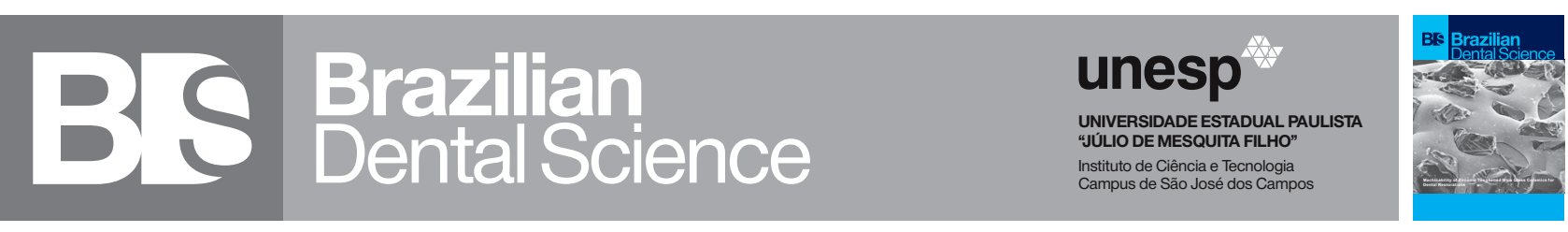

\title{
Knowledge about composite restorations repair vs replacement- a survey among a subpopulation of saudi dental students
}

\author{
Conhecimento sobre reparo e substituição de restaurações de resina - uma pesquisa entre uma subpopulação de \\ estudantes sauditas de odontologia

\begin{abstract}
Mohammed A Al-QARNI ${ }^{1}$, Shamsun Nahar KHALIL ${ }^{2}$, Eman Saeed Saeed OBIED ${ }^{3}$, Maha M ALSHEHRI ${ }^{3}$, Manar Ali Abdulgader ASSIRI $^{3}$, Sara Abdullah Muhammed MUALWI ${ }^{3}$, Sultanah Mohammed Saeed THABET ${ }^{3}$, Shafait Ullah KHATEEB ${ }^{1}$

1 - Department Of Restorative Dental Sciences, College Of Dentistry, King Khalid University, Abha, Kingdom Of Saudi Arabia.

2 - Family And Community Medicine, College Of Medicine, King Khalid University, Abha, Kingdom Of Saudi Arabia.

3 - Department of Restorative Dental Sciences, College Of Dentistry, King Khalid University, Abha, Kingdom Of Saudi Arabia.
\end{abstract}

\section{ABSTRACT}

Objective: The purpose of this study was to evaluate the knowledge among dental students at King Khalid University, Jazan University, and Najran University in the kingdom of Saudi Arabia about when to repair or replace defective direct composite restoration. Materials and Methods: A questionnaire-based survey was formulated, pursuing the information about management (repair/replacement) of defective composite restorations and distributed among 200 dental students of three universities in the southern region of the kingdom of Saudi Arabia. The data were collected with the help of an online questionnaire. Data entry and the analysis were done using the statistical software package SPSS version 20.0. It was presented using descriptive statistics in the form of frequencies and percentages for qualitative variables, and range means and standard deviations for age, quantitative variable. Analytic statistics were done using Chi-Square tests $(\mathrm{x} 2)$ to test the significant difference between categorical variables. The level of significance, the p-value was $0.01(\mathrm{p}<0.01)$. Results: The decision to choose between composite repair or replacement was influenced by whether this topic was taught to them at various undergraduate levels during Bachelor of Dental Surgery. The reason associated with the decision to repair defective composite restorations, $76 \%$ reported as cost-effective followed by Increased longevity (71\%), the permanent filling (70\%), patient's preference for repair (65\%), and least time consuming (50\%). 67\% participants preferred significantly $(\mathrm{p}<0.001)$ repair due to secondary caries in the previously restored tooth with composite, followed by the small surface defect in a composite restoration (65\%), risk of pulpal damage significantly $(\mathrm{p}<0.001)$ in a defective composite restoration $(62.5 \%)$ and more invasive and destructive treatment option (35\%). More than half of respondents $123(61.5 \%)$ reported that they were not taught about composite repair during the Bachelor of Dental

\section{RESUMO}

Objetivo: O objetivo deste estudo foi avaliar o conhecimento entre estudantes de odontologia da King Khalid University, Jazan University e Najran University, no reino da Arábia Saudita, sobre quando reparar ou substituir restaurações de resina composta direta defeituosas. Material e Métodos: Foi formulada uma pesquisa baseada em questionário, buscando informações sobre o manejo (reparo / substituição) de restaurações de resina composta e distribuída entre 200 estudantes de odontologia de três universidades da região sul do reino da Arábia Saudita. Os dados foram coletados com o auxílio de um questionário online. A entrada e análise dos dados foram feitas com o software estatístico SPSS versão 20.0. Foi apresentado por meio de estatística descritiva na forma de frequências e percentuais para as variáveis qualitativas, e amplitude de médias e desvios-padrão para a idade, variável quantitativa. A estatística analítica foi feita usando testes de qui-quadrado $(x 2)$ para testar a diferença significativa entre as variáveis categóricas. Ao nível de significância, o valor de $\mathrm{p}$ foi de $0,01(\mathrm{p}<0,01)$. Resultados: A decisão de escolher entre o reparo ou substituição do compósito foi influenciada pelo fato de este tópico ter sido ensinado a eles em vários níveis de graduação durante o Bacharelado em Odontologia. O motivo associado à decisão de reparar restaurações de resina composta defeituosas, $76 \%$ relataram como custobenefício seguido por maior longevidade (71\%), restauração definitva (70\%), preferência do paciente para reparo (65\%) e menos demorado ( $50 \%$ ). Sessenta e sete por cento dos participantes preferiram o reparo significativamente ( $p$ $<0,001$ ) devido a cárie secundária no dente previamente restaurado com resina composta, seguido pelo pequeno defeito de superfície em uma restauração composta (65\%), risco de dano pulpar significativamente ( $p<0,001)$ em um restauração de resina composta com defeito $(62,5 \%)$ e opção de tratamento mais invasiva e destrutiva (35\%). Mais da metade dos entrevistados, 123 (61,5\%) relataram que não foram ensinados sobre reparo de resina composta durante o Bacharelado em Odonotlogia. Conclusão: É sugerido com a ajuda de nosso estudo que os componentes 
Surgery. Conclusion: It is suggested with the help of our study that didactic and clinical training components regarding composite repair should be seriously included in the teaching curriculum of dental institutions as it is in the best interest of the patient. Dental students should be provided with clinical training on this topic so that they can follow proper decision-making protocols available during repair or replacement of defective resin composite restorations. Other researches in the future can be carried out for refining the guidelines and techniques utilized for composite repair.

\section{KEYWORDS}

Composite restoration; Discoloration; Polymerization shrinkage; Secondary caries. do treinamento didático e clínico sobre reparo de resina composta devem ser seriamente incluídos no currículo de ensino de instituições odontológicas, pois é do interesse do paciente. Os estudantes de odontologia devem receber treinamento clínico sobre este tópico para que possam seguir os protocolos de tomada de decisão adequados disponíveis durante o reparo ou substituição de restaurações de resina composta com defeito. Outras pesquisas no futuro podem ser realizadas para refinar as diretrizes e técnicas utilizadas para reparo de resina.

\section{PALAVRAS-CHAVE}

Restauração de compósitos; Manchamento; Contração de polimerização; Cárie secundária.

\section{INTRODUCTION}

$\mathrm{R}$ ecently direct resin-composite is widely used in $\Omega$ dental practice due to its preferred tooth-color matching and recent modifications like improved mechanical properties. Nowadays it can be used in posterior teeth to withstand occlusal forces. The longevity of these materials can be disappointing, especially if not placed using a careful incremental technique [1]. Dental restorations tend to have a limited service life in a harsh oral environment and be prone to failure. So when placed into the hostile oral environment, composites commonly suffer deterioration and degradation in clinical service over time [2]. Composite restorations may fail because of biological, mechanical, and or aesthetic factors and when defective need secondary intervention in the form of refurbishment, replacement, or repair. The annual failure rates of anterior and posterior composite restorations commonly vary between $1 \%$ and $4 \%[3,4]$.

Refurbishing means that no material or dental structure will be removed and additional restorative material will be added to fix the restoration. The repair involves partial removal of the defective part of the restoration, which is then repaired with new material to complete the restoration. Replacing a restoration involves complete removal of the restorative (even portions that might appear clinically acceptable) for the placement of new material [4]. The decision making during the management of local defects in composite restoration is at times challenging in clinical practice. Traditionally, the accepted treatment standard for restorations exhibiting signs of deterioration and failure was the total replacement [3]. With the recent concept of minimal intervention dentistry, shifting towards repairing rather than replacing direct resincomposite restorations are in a great field of interest. Replacement can cause unnecessary removal of tooth structure in locations often distant from the site of the deteriorating restoration and the tooth becomes weaker, invariably resulting in acceleration of the "restoration death spiral" $[5,6]$. It's a time-consuming procedure and can cause pulpal irritation and/or pulpal exposure inviting more complex treatment options like endodontic or prosthodontic measures. [1,2]. Repairing of the defective composite restorations has many advantages. The main advantage is the preservation of tooth structure, leaving restored teeth better to withstand loads in function and, as a result, an improved prognosis [6]. Other advantages of repairing a defective restoration are that it is an easy procedure, offers increased longevity of the restoration. It is less time consuming due to less complexity. It is cost-effective and less likely to result in iatrogenic damage or repetitive trauma, hence less traumatic to the patient. This procedure reduces the need for local anesthesia, which will reduce patient anxiety, and increases the cooperation and acceptance by the patient $[1,6-8]$.

According to Paul. A. Brunton, there are no practice guidelines available on the clear indications and techniques of repairing direct resin-composite [9]. While Blum IR had provided clear indications, contraindications, and techniques of repair 
$[2,6]$. The evidence base for repair rather than a replacement for the management of defective and failing restorations continues to improve and establish [10]. With progress in adhesive dentistry, 'reparative dentistry' is becoming an important field of minimally invasive dentistry [11] and has become a vital part of dental undergraduate teaching worldwide [2]. There is substantially increasing evidence favoring repair rather than replacement as a treatment option for defective or failing composite restorations [12], therefore, this study aimed to evaluate the knowledge among dental students about when to repair or replace defective direct composite restorations.

\section{MATERIALS AND METHODS}

A cross-sectional descriptive study was conducted among dental students at King Khalid University, Jazan University, and Najran University in the southern region of the kingdom of Saudi Arabia using anonymous structured and closed-ended questionnaire as the instrument for data collection (Frame 1). A survey questionnaire (consisting of 17 questions) was formulated and distributed to 200 dental students in 3 different dental schools in the southern region of the kingdom of Saudi Arabia. The study group ( $\mathrm{n}=$ 200) consisted of Saudi dental students from the 6 th $-12^{\text {th }}$ levels of Bachelor of Dental Surgery. Participants were informed that their demographic variables will be kept confidential. The survey was carried out from the 10th of June 2018 to the 07th of July 2018. The survey assessed the knowledge of Saudi dental students about the indications and contraindications of repair and replacement of defective/failing direct composite restoration. It inquired about the ability of Saudi dental students to make a clear decision about whether to repair or replace defective direct composite restorations. The returned questionnaires were encrypted and the data entry and analysis was done using Statistical Package for the Social Sciences (SPSS) Version 20.0. It was presented using descriptive statistics in the form of frequencies and percentages for qualitative variables, and range means and standard deviations for quantitative variables. Analytic statistics were made using Chi-Square tests $(\mathrm{x} 2)$ to test the significance of the difference for categorical variables. The $\mathrm{p}$-value equal to or less than 0.01 was considered as significant value. Ethical clearance (REC \# 2018-04-12) was obtained from the ethical committee.
Frame 1 - The following questionnaire aims to estimate the knowledge of the composite restoration repair VS replacement among Saudi dental students in southern region.

\begin{tabular}{|c|c|c|}
\hline S.No & & \\
\hline 1 & Age: & \\
\hline 2 & Dental student: level: & $6(1), 7(2), 8(3), 9(4), 10(5), 11(6), 12(7)$ \\
\hline 3 & College: & $\begin{array}{l}\text { King Khalid University(1) - Jazan } \\
\text { university(2) - Najran university(3) }\end{array}$ \\
\hline 4 & Address: & $\begin{array}{l}\text { Abha (1), Jazan(2), Najran(3), other } \\
\text { place in Southern Region(4) }\end{array}$ \\
\hline 5 & $\begin{array}{l}\text { Have you been taught } \\
\text { about indications and } \\
\text { technique of composite } \\
\text { repair during Bachelor of } \\
\text { Dental Surgery. }\end{array}$ & Yes(1)-No(2) \\
\hline 6 & $\begin{array}{l}\text { Have you replaced a defec- } \\
\text { tive composite restoration }\end{array}$ & Yes(1)-No(2) \\
\hline 7 & $\begin{array}{l}\text { Have you repaired the } \\
\text { composite restoration }\end{array}$ & Yes(1)-No(2) \\
\hline 8 & $\begin{array}{l}\text { Treatment choice in a small } \\
\text { surface defect of a compo- } \\
\text { site restoration. }\end{array}$ & Repair(1) - Replacement(2) \\
\hline 9 & $\begin{array}{l}\text { The presence of secondary } \\
\text { caries in a previously resto- } \\
\text { red tooth with composite is } \\
\text { an indication of }\end{array}$ & Repair(1) - Replacement(2) \\
\hline 10 & $\begin{array}{l}\text { Risk of pulpal damage in a } \\
\text { defective composite resto- } \\
\text { ration can be avoided by }\end{array}$ & Repair(1) - Replacement(2) \\
\hline 11 & $\begin{array}{l}\text { Which one is a more } \\
\text { invasive and destructive } \\
\text { treatment option }\end{array}$ & Repair(1) - Replacement(2) \\
\hline 12 & $\begin{array}{l}\text { What is the most common } \\
\text { situation that needs } \\
\text { repair? }\end{array}$ & $\begin{array}{l}\text { Discolor of the restoration (1) - Par- } \\
\text { tial loss of composite(2)-Secondary } \\
\text { caries(3)- Fracture of restoration(4) }\end{array}$ \\
\hline 13 & $\begin{array}{l}\text { During decision making to } \\
\text { repair defective compo- } \\
\text { site restorations patient's } \\
\text { preference should be } \\
\text { considered }\end{array}$ & Yes(1)-No(2) \\
\hline 14 & $\begin{array}{l}\text { Which one is a more Cost- } \\
\text {-effective treatment option }\end{array}$ & Repair(1) - Replacement(2) \\
\hline 15 & $\begin{array}{l}\text { Repair is least time consu- } \\
\text { ming than replacement }\end{array}$ & Yes(1) - No(2) \\
\hline 16 & $\begin{array}{l}\text { Increased longevity of a } \\
\text { defective restoration is } \\
\text { expected in case of }\end{array}$ & Repair(1) - Replacement(2) \\
\hline 17 & $\begin{array}{l}\text { Which one is considered a } \\
\text { permanent filling }\end{array}$ & Repair(1) - Replacement(2) \\
\hline
\end{tabular}

\section{RESULTS}

The respondents have their age mean \pm SD $(23.19 \pm 1.639)$ and range $(10-30)$ years. The questionnaire responses were received from dental students giving a response rate of $100 \%$ 
(200 participants). No incomplete responses were received. The most common indication for repair reported by the participating dental students was secondary caries (37\%) and significantly higher $(\mathrm{p}=$ 0.001), than other factors evaluated (Table I). On asking for the reason associated with the decision to repair defective composite restorations $76 \%$ announced as cost-effective followed by increased longevity (71\%) (Table II). 67\% participants preferred significantly $(\mathrm{p}<0.001)$ repair due to secondary caries in the previously restored tooth with composite, followed by the small surface defect in a composite restoration $(65 \%)$, the risk of pulpal damage significantly $(\mathrm{p}<0.001)$ in a defective composite restoration $(62.5 \%)$ and more invasive and destructive treatment option (35\%) (Table III). More than half of respondents 123 (61.5\%) reported that they were not taught about composite repair during the Bachelor of Dental Surgery training (Table IV).

Table I - Most common indications of composite repair

\begin{tabular}{|c|c|}
\hline $\begin{array}{l}\text { The most common indication for } \\
\text { repair }\end{array}$ & Respondent, $n=200(\%)$ \\
\hline Discoloration & $35(17.5)$ \\
\hline Partial loss of composite & $59(29.5)$ \\
\hline Secondary caries & $74(37)$ \\
\hline Fracture of restoration & $32(16)$ \\
\hline Pearson's Chi-square $=24.120$, & $3, p$ value $=0.001^{\star}$ \\
\hline
\end{tabular}

${ }^{*}$ Highly significant $p<0.01$

Table II - Reason associated with the decision to repair defective composite restorations

\begin{tabular}{|lc|}
\hline $\begin{array}{c}\text { Reason for repair rather the replace- } \\
\text { ment }\end{array}$ & $\begin{array}{c}\text { Cost-effective } \\
\text { Respondents, } \mathbf{n = 2 0 0 ( \% )}\end{array}$ \\
\hline $\begin{array}{c}\text { Least time consuming than replacement } \\
\text { Increased longevity of a repair restoration }\end{array}$ & $100(50 \%)$ \\
\hline $\begin{array}{c}\text { Repaired restoration is considered perma- } \\
\text { nent filling }\end{array}$ & $142(71 \%)$ \\
\hline \begin{tabular}{c} 
Ask about the patient's preference for repair \\
\hline
\end{tabular} & $140(70 \%)$ \\
\hline
\end{tabular}

Table III - Participant's treatment choice in a clinical scenario of a defective composite restoration

\begin{tabular}{|c|c|c|c|}
\hline $\begin{array}{l}\text { Treatment } \\
\text { option }\end{array}$ & Repair n(\%) & $\begin{array}{l}\text { Replace- } \\
\text { ment n(\%) }\end{array}$ & $\begin{array}{c}\text { Pearson's } \\
\text { Chi-square } \\
\text { (p-value) }\end{array}$ \\
\hline $\begin{array}{l}\text { A small surface } \\
\text { defect in a compo- } \\
\text { site restoration }\end{array}$ & $130(65 \%)$ & $70(35 \%)$ & $18.000\left(0.001^{\star}\right)$ \\
\hline $\begin{array}{l}\text { Risk of pulpal } \\
\text { damage in a de- } \\
\text { fective composite } \\
\text { restoration can be } \\
\text { avoided }\end{array}$ & $125(62.5 \%)$ & 75(37.5\%) & $12.500\left(0.001^{*}\right)$ \\
\hline $\begin{array}{l}\text { A more invasive } \\
\text { and destructive } \\
\text { treatment option }\end{array}$ & $70(35 \%)$ & $130(65 \%)$ & $18.000\left(0.001^{\star}\right)$ \\
\hline $\begin{array}{l}\text { Secondary caries } \\
\text { in a previously } \\
\text { restored tooth with } \\
\text { composite is an } \\
\text { indication }\end{array}$ & $134(67 \%)$ & $66(33 \%)$ & $23.120\left(0.001^{*}\right)$ \\
\hline
\end{tabular}

*Highly significant $p<0.01$

Table IV - Response of participants to survey questions related to knowledge and practices of composite repair and replacement

\begin{tabular}{|ccc|}
\hline $\begin{array}{c}\text { Knowledge and attitude question } \\
\text { Response n= 200(\%) }\end{array}$ & Yes & No \\
\hline $\begin{array}{c}\text { Have you been taught about indications and } \\
\text { technique of composite repair during Bachelor } \\
\text { of Dental Surgery. }\end{array}$ & $77(38.5)$ & $123(61.5)$ \\
\hline $\begin{array}{c}\text { Have you replaced a defective composite } \\
\text { restoration }\end{array}$ & $164(82 \%)$ & $36(18 \%)$ \\
\hline Have you repaired the composite restoration & $123(61.5)$ & $77(38.5)$ \\
\hline
\end{tabular}

\section{DISCUSSION}

This study aimed to investigate the teaching and knowledge of the repair, rather than replacement, of failing Direct Composite Restorations in dental schools in the southern region of the kingdom of Saudi Arabia. Online data collection is typically found to be efficient, effective, and relatively inexpensive, but it has been reported to yield lower response rates than paper-based/postal surveys [13]. As with all questionnaire-based surveys, risks exist concerning the reliability of responses and the potential of non-response bias. Our study had a 100\% response rate and another advantage of this study was that the group $(n=200)$ of dental students were belonging to three different universities/cities in the southern region of the kingdom of Saudi Arabia 
so it was a multi-center survey design, providing data of stronger power of inference. The excellent response rate $(100 \%)$, signifies the importance of the topic and the inclination of the dental schools in the southern region of the kingdom of Saudi Arabia to engage in research.

In this study, most of the questions used had been evaluated and found to be appropriate for related studies [14-16]. Thus, the findings of the present study expressed an important insight into the management (repair/replacement) of defective composite restorations in the southern region of the kingdom of Saudi Arabia. The results are consistent with the findings of previously published studies [12,17-19]. Even though 61.5 $\%$ of the respondents reported that they have performed repairs to Direct Composite Restorations equal number of the respondents reported that they have not been taught about indications and techniques of composite repair during Bachelor of Dental Surgery. This is per many studies that have reported that composite restoration repair was not taught to dental undergraduate students $[9,20]$. The present study emphasizes including the theoretical and clinical teaching of composite repair in the curriculum within the coming time. It would be rewarding for the students to be well versed with the guidelines and protocol in terms of the theory of repair versus replacement before entering the clinical settings.

There are a strong association and agreement between academicians in conservative dentistry around the world that there are certain benefits in repairing instead of replacing defective direct resin composite restorations [6,19,21-22]. Recent studies have reported on the success of repairs to Direct Composite Restorations and analyzed the techniques used to ensure longevity and optimum results [9]. This study revealed that $71 \%$ of the respondents reported that repair increased the longevity of the restoration. Our results are in agreement with the findings of Gordan et al. who reviewed the information published regarding the repair of composite restorations and concluded that repaired restorations had a higher survival rate; improved sealing of crevice or ditch with superior longevity when put next to restorations which remained untreated [23]. Defective or failing composite restorations can be salvaged to extend longevity by repairing the composite restoration [22].
This study has unfolded many clinical and patient-related factors influencing the reasons with the decision to repair like the patient preference for repair. These findings are consistent with the findings of Hickel and Manhart, who claimed that clinician factors, material properties, and patient factors influence the repair or replacement of defective or failing restoration [24]. Rehabilitation may be a minimal intervention approach to treat the faults which are superficial, while localized defects that are easy to approach are treated by repairing [25-26].In this study, $65 \%$ of the students preferred repair over replacement for a small surface defect in composite restoration.

The beneficial point about this minimal intervention approach of defective restorations may be a restored tooth with less removal of healthy tooth tissue, which is strong and withstand better for functional loads which leads to better future prognosis. A restoration that is replaced tends to be larger than the one it is replacing therefore, extensive restorations have shorter longevity than smaller restorations in clinical service [12]. Most of the institutions regard repair as a minimally invasive treatment option which leads to delaying the degradation or failure of restorations [27]. In this study, it was reported that replacement (65\%) is a more invasive and destructive treatment option, which is per the other studies demarcating that repair is a conservative treatment alternative $[1,12,28]$.

It is reported that approximately half of all restorations placed are done to interchange existing defective restorations $[21,29]$. The results of our study show that the replacement of faulty restorations $(82 \%)$ is a preferred alternative, this may be because of students following the outdated dogma of 'if in doubt, take it out' [6] or lack/ deficiency of information on the topic drives their decision for repair or replacement of restorations. Students should be encouraged to adopt the modern mantra of "as a last resort, take it out" and to concurrently apply modern techniques for the refurbishment and repair of defective restorations. This finding is in confirmatory to a dental practicebased research study, involving 197 clinicians in the USA and Scandinavian countries, which also designated that when contemplating treatment options for restorations with localized defects, in over $75 \%$ of cases the practitioners choose replacement rather than repair $[6,10]$. 
Previous studies have reported that replacement of a previously restored composite restoration is time-consuming, which may cause pulpal damage because of non-required tooth structure destruction, and can reduce the resistance to fracture $[19,30]$. In this study it was revealed that risk of pulpal damage can be avoided significantly $(\mathrm{P}<0.001)$ during repair of defective composite restoration.

The longevity of restorations and the cost of replacing restorations are two significant factors determining the long-term cost of restorative therapy. The major advantage of repair treatment is that it saves tooth structure and patient-chair time. A further detrimental consequence of the restoration replacement approach includes the misuse of patients' time, resources, and tolerance to accept interventive dental care $[2,11]$. Performing restoration repair, if appropriate, may conserve tooth structure and is less time consuming because of better patient experience and in some cases needs no local anesthesia $[22,30]$. These findings substantiate our finding during which $76 \%$ of the respondents agreed that repair was cost-effective and $50 \%$ reported that it is less time consuming than replacement. It's critical to pick a minimally invasive treatment option for restorations that have already been done to extend the longevity of the remaining part of the restoration and the restored tooth unit. The most common reason for repair was found to be secondary caries (43\%) by Gordon et al [21] and (37\%) by Fayyaz et al [12], and others [30-31] whereas the results of the present study indicated that secondary caries (67\%) was also the foremost common repair indication selected by the participants. Most universities have reported that they should include the teaching of composite repair techniques in the dental curriculum $[16,19,22]$. The findings of our study revealed that the majority of dental students haven't received didactic instructions about various factors during their undergraduate dental training to contemplate composite repair as a viable treatment option for defective restorations. Only $38.5 \%$ of dental students claimed that they were taught or trained for the topic of composite repair during Bachelor of Dental Surgery and only $61.5 \%$ of the participants recognized repair as a treatment option in case of its requirement.

The effective repair of composite restorations requires theoretical knowledge and understanding of the effects of the various operative interventions and materials used. The specific techniques used for the repair of Direct Composite Restorations in each school were not investigated in this study. Future clinical studies should investigate the various repair intervention techniques affecting the clinical performance of repairs, including the effects of bonding new composite to composite which has been exposed to the oral environment for different intervals of time. Our study does not represent a multinational questionnaire survey. The results are based on a low number of dental schools, thus the projection to other countries remains questionable. Another limitation of this study is that it has not analyzed the effects of factors such as operator skills and experience, and material properties in the management of defective direct composite restorations.

\section{CONCLUSION}

It is suggested with the help of our study that the teaching of composite repair should be seriously included in teaching institutions as it is in the best interest of the patient. Dental students should be provided with clinical training on this topic. Scientific societies in Operative Dentistry should draft guidelines on the repair of partially defective or failing restorations so that uniform protocols would be followed by teachers, students, and dental practitioners.

Also, a recall system to monitor clinical performance for repaired restorations should be instituted, so that data will be available on how long composite repairs undertaken in dental schools in the southern region of the kingdom of Saudi Arabia will last in clinical service. Future research can be carried out for refining the guidelines and techniques utilized for composite repair and should also address clinical factors such as the role of the original restoration's dimension in the success of Direct Composite Restoration repairs, and the effect of various parafunctional habits in the survival of repairs placed on different areas of anterior and posterior dentition.

\section{Acknowledgments}

The authors are grateful to Dr.Suheel Manzoor Baba for content contributions, and the support during the development and writing of these manuscript. 


\section{Funding}

None.

\section{Conflict of interest}

The authors have no proprietary, financial, or other personal interest of any nature or kind in any product, service, and/or company that is presented in this article.

\section{Regulatory Statement}

This study was conducted in accordance with all the provisions of the local human subjects oversight committee guidelines and policies of:Reseasrch Ethics Committee, King Khalid University,Abha,Kingdom of Saudi Arabia. The approval code for this study is: REC \# 2018-04-12.

\section{REFERENCES}

1. Blum IR, Jagger DC, Wilson NH. Defective dental restorations: to repair or not to repair? Part 1: direct composite restorations. Dent Update. 2011Mar;38(2):7880,82-4. doi:10.12968/denu.2011.38.278.PMID:21500616.

2. Blum IR. Restoration Repair as a Contemporary Approach to Tooth Preservation: Criteria for Decision Making and Clinical Recommendations. Prim Dent J. 2019 May 20;8(1):38-42. doi: 10.1308/205016819826439466. PMID: 31122330.

3. Lynch CD, Blum IR, Frazier KB, Haisch LD, Wilson NH. Repair or replacement of defective direct resin-based composite restorations: contemporary teaching in U.S. and Canadian dental schools. J Am Dent Assoc. 2012 Feb;143(2):157-63. do::10.14219/jada.archive.2012.0126.PMID:22298557.

4. Valente LL, Sarkis-Onofre R, Goncalves AP,FernandezE, Loomans B, Moraes RR. Repair bond strength of dental composites: systematic review and meta-analysis. Int J Adhes Adhesives. 2016 Sep 1;69:15-26. doi:10.1016/j. ijadhadh.2016.03.020

5. Elderton R.Principles in the management and treatment of dental caries. In: Elderton R, editor. The Dentition and Dental Care. Oxford, UK: Heinemann Medical Books; 1990

6. Blum IR, Lynch CD, Wilson NH. Factors influencing repair of dental restorations with resin composite. Clin Cosmet Investig Dent. 2014 0ct 17;6:81-7. doi: 10.2147/CCIDES53461.PMID:25378952; PMCID:PMC4207439.

7. Mjör IA. Repair versus replacement of failed restorations. IntDent J. 1993 Oct:43(5):466-72.PMID:8138309.

8. van de SandeFH,Moraes RR, Elias RV, Montagner AF, Rodolpho PA, Demarco $\mathrm{FF}$, Cenci MS. Is composite repair suitable for anterior restorations? A long-term practice-based clinical study. Clin Oral Investig. 2019 Jun;23(6):27952803. doi:101007/s00784-018-2722-5. Epub 2018 0ct27.PMID:30368661.

9. Brunton PA, Ghazali A, Tarif ZH, Loch C, Lynch C, Wilson N, Blum IR. Repair vs replacement of direct composite restorations: a survey of teaching and operative techniques in 0ceania. J Dent. 2017 Apr;59:62-67. doi:10.1016/j. jdent.2017.02.010. Epub 2017 Feb 20.PMID:28232082.

10. Wilson N, Lynch CD, Brunton PA, Hickel R, Meyer-Lueckel H, Gurgan S, Pallesen U, Shearer AC, TarleZ, CottiE, Vanherle G, Opdam N. Criteria for the Replacement of Restorations: Academy of Operative Dentistry European Section. Oper Dent. 2016 Sep;41(S7):S48-S57.doi: 10.2341/15-058-0.PMID: 27689930.
11. Blum IR,Özcan M. Reparative Dentistry: Possibilities and Limitations. Curr Oral Health Rep. 2018:5(4):264-269. doi:10.1007/s40496-018-0191-1. Epub 2018 Sep 15.PMID: 30524930;PMCID:PMC6244566.

12. Fayyaz A, Fareed MA, Ehsan S, Baig QA, Noor NA. Repair or replacement of defective direct composite restorations: a survey of dentists. J Pakistan Dent Association. 2015 Jan;24(1):17-21.

13. H. McDonald, S. Adam, A comparison of online and postal data collection methods in marketing research. Marketing Intel Plann. 2003;21(2):85-95. doi: 10.1108/02634500310465399

14. Blum IR, Mjör IA, Schriever A, Heidemann D, Wilson NH. Defective direct composite restorations--replace or repair? A survey of teaching in Scandinavian dental schools. Swed Dent J. 2003;27(3):99-104. PMID: 14608966.

15. Blum IR, Lynch CD, Schriever A, Heidemann D, Wilson NH. Repair versus replacement of defective composite restorations in dental schools in Germany. Eur J Prosthodont Restor Dent. 2011 Jun;19(2):56-61.PMID:21780727.

16. Blum IR, Lynch CD, Wilson NH. Teaching of direct composite restoration repair in undergraduate dental schools in the United Kingdom and Ireland. Eur J Dent Educ. 2012Feb;16(1):e53-8. doi:10.1111/j.1600-0579.2010.00674.x. Epub 2011 Jan 13.PMID:22251354.

17. Opdam NJ, BronkhorstEM, Loomans BA, Huysmans MC. Longevity of repaired restorations: a practice based study. J Dent. 20120ct;40(10):829-35. doi: 10.1016/j.jdent.2012.06.007. Epub 2012 Jul 4.PMID:22771415.

18. Gordan VV, Riley JL 3rd, Worley DC, Gillbert GH; DPBRN Collaborative Group. Restorative material and other tooth-specific variables associated with the decision to repair or replace defective restorations: findings from The Dental PBRN. J Dent. 2012 May;40(5):397-405. doi: 10.1016/j.jdent.2012.02.001. Epub 2012Feb 8.PMID:22342563;PMCID:PMC3322253.

19. Lynch CD, Frazier KB, McConnell RJ, Blum IR, Wilson NH. Minimally invasive management of dental caries: contemporary teaching of posterior resinbased composite placement in U.S. and Canadian dental schools. J Am Dent Assoc. 2011 Jun;142(6):612-20. doi: 10.14219/jada.archive.2011.0243. PMID: 21628682.

20. Blum IR, Schriever A, Heidemann D, Mjör IA, Wilson NH. The repair of direct composite restorations: an international survey of the teaching of operative techniques and materials. Eur J DentEduc. 2003Feb;7(1):41-8. doi: 10.1034/1.1600-0579.2003.00275.x.PMID: 12542688.

21. Gordan VV, Riley JL 3rd, Geraldeli S, Rindal DB, Qvist V, Fellows JL, Kellum HP, Gilbert GH;Dental Practice-Based Research Network Collaborative Group. Repair or replacement of defective restorations by dentists in The Dental Practice-Based Research Network. J Am Dent Assoc. 2012 Jun;143(6):593601. doi: 10.14219/jada.archive.2012.0238.PMID:22653939;PMCID: PMC3368503.

22. Blum IR, Lynch CD, Wilson NH. Teaching of the repair of defective composite restorations in Scandinavian dental schools. J Oral Rehabil. 2012 Mar;39(3):2106. doi:10.1111/.j.1365-2842.2011.02260.x. Epub20110ct6.PMID:21972940.

23. Gordan W, Garvan CW, Blaser PK, Mondragon E, Mjör IA. A long-term evaluation of alternative treatments to replacement of resin-based composite restorations: results of a seven-year study. J Am Dent Assoc. 2009 Dec;140(12):1476-84. doi: 10.14219/jada.archive.2009.0098.PMID: 19955065.

24. ManhartJ, Chen H,Hamm G, Hickel R. Buonocore Memorial Lecture. Review of the clinical survival of direct and indirect restorations in posterior teeth of the permanent dentition. Oper Dent. 2004 Sep-0ct;29(5):481-508. PMID: 15470871

25. Lynch CD, Wilson NH. Managing the phase-down of amalgam: Partl. Educational and training issues. Br Dent J. 2013 Aug;215(3):109-13. doi: 10.1038/ sj.bdj.2013.737.PMID:23928599. 
26. Gordan VV. Clinical evaluation of replacement of class V resin based composite restorations. J Dent. 2001Sep;29(7):485-8. doi:10.1016/s0300-5712(01)000306.PMID: 11809326

27. Hickel R, Brüshaver K, llie N. Repair of restorations--criteria for decision making and clinical recommendations. Dent Mater.2013 Jan;29(1):28-50. doi:10.1016/j. dental.2012.07.006. Epub 2012 Aug 3.PMID:22867859.

28. Kanzow P,Hoffmann R, Tschammler C, Kruppa J, Rödig T, Wiegand A. Attitudes, practice, and experience of German dentists regarding repair restorations. Clin Oral Investig. 2017 May;21(4):1087-1093. doi: 10.1007/s00784-016-1859-3. Epub 2016 Jun2.PMID:27255959.
29. Mij̈r IA, Moorhead JE, Dahl JE Reasons for replacement of restorations in permanent teeth in general dental practice. IntDent J.2000 Dec;50(6):361-6. doi:10.1111/j.1875-595x.2000.tb00569.x.PMID: 11197194.

30. Yousef MK, KhojaNH. Repair and replacement perception of dental restorations. Journal King Abdulaziz University-Medical Sciences. 2009 Jan 4;16(1):75-85. doi: 10.4197/Med.16-1.7

31. Mjör IA, Gordan V. Failure, repair, refurbishing and longevity of restorations. Oper Dent. 2002 Sep-0ct;27(5):528-34.PMID: 12216574.

\section{Shafait Ullah KHATEEB}

(Corresponding address)

Department Of Restorative Dental Sciences, College Of Dentistry, King Khalid

University, Abha, Kingdom Of Saudi Arabia.

Guraiger, Abha 62529

Date submitted: 2020 May 31

E-mail: shafait786786@gmail.com 